\title{
Live Pig Skin Tissue and Wound Toxic ity of Cold Plasma Treatment
}

\author{
Danil Dobrynin ${ }^{1}$, Andrew Wu ${ }^{2}$, Sameer Kalghatgi ${ }^{1}$, Sin Park $^{3}$, Natalie Shainsky ${ }^{1}$, \\ Kimberly Wasko², Essel Dumani ${ }^{4}$, Robert Ownbey ${ }^{4}$, Suresh Joshi², \\ Rachel Sensenig², Ari D Brooks² \\ ${ }^{1}$ Electrical and Computer Engineering Department, Drexel University, Philadelphia, PA²Depart- \\ ment of Surgery, Drexel University College of Medicine, Philadelphia, PA ${ }^{3}$ School of Biomedical \\ Engineering, Drexel University, Philadelphia, PA ${ }^{4}$ Department of Pathology, Drexel University \\ College of Medicine, Philadelphia, PA
}

\begin{abstract}
Cold atmospheric pressure plasmas have emerged as a promising new tool for medical applications. Compared to conventional thermal plasma, such as arc coagulators and desiccators, cold plasma can be more selective in its application and may be used for effective sterilization of skin and wound tissue, wound healing and tissue regeneration, cancer treatment and blood coagulation. One of the key questions that has to be answered before these plasma technologies are introduced in medical practice is the safety of plasma treatment of living tissues, i.e. toxic dose levels of plasma exposure should be determined. It is well established that porcine (pig) skin closely resembles human skin; hence we evaluated the potential toxic effects of plasma treatment on intact and wounded skin in a Yorkshire pig model. Varying doses of Floating Electrode Dielectric Barrier Discharge (FE-DBD) and microsecond Pin-toHole Spark Discharge (PHD) plasmas were applied to determine a dosage regime where tissue damage occurs.
\end{abstract}

KEY WORDS: Non-equilibrium plasma, cold plasma, dielectric barrier discharge, spark discharge, skin toxicity, animal model, plasma medicine

\section{INTRODUCTION}

It is evident from the large number of recent reviews in the literature that there are many potential applications of non-equilibrium plasma discharges in biology and in medicine. ${ }^{1-10}$ This is, in part, driven by the continued development of novel plasma sources and modification of existing ones ${ }^{1,411-21}$ and by advances in modeling, simulation, and characterization of these sources, including characterization and quantification of biological effects ${ }^{1,11,22-34}$. The major focus in applications of plasma in medicine has been its antimicrobial effect, although some reports of wound healing applications have been presented $^{3,6,11,15,29,35,36}$. In studying antimicrobial effects of plasma it is essential to evaluate the potential damage plasma can inflict on living tissues.

This manuscript investigates toxicity in the direct application of two different types of plasma to living tissue: (a) Floating Electrode Dielectric Barrier Discharge which is an inherently non-thermal discharge that generates a multitude of reactive oxygen species (ROS) and (b) Pin-to-Hole spark Discharge which is a thermal discharge that generates ROS together with reactive nitrogen species (RNS). Both discharges have been considered before for antimicrobial treatment of living tissues. However, little work has 
been reported on the possible damage these discharges could inflict in the process. We show that low doses of plasma (previously reported to be quite sufficient for sterilization, see ${ }^{10,37}$ for example) do not cause any visible or microscopic damage to live pig skin and wound tissue. Higher doses do, in fact, cause damage and the damage appears to be related to the surface temperature of the tissue. Thus, if the plasma temperature is reduced (through shorter pulses, for example) this heating and thus the damage may potentially be avoided.

\section{MATERIALS AND METHODS}

\section{A. Foating Electrode Dielectric Bamier Discharge (FE-DBD)}

Non-thermal atmospheric pressure dielectric barrier discharge plasma was generated using an experimental setup similar to the one previously described by the authors ${ }^{38-42}$. In short, the discharge was generated by applying alternating polarity pulsed $(500 \mathrm{~Hz}$ $-1.5 \mathrm{kHz}$ ) voltage of $\sim 20 \mathrm{kV}$ magnitude (peak to peak), $1.65 \mu$ s pulse width and a rise time of $5 \mathrm{~V} / \mathrm{ns}$ between the insulated high voltage electrode and the sample undergoing treatment. One mm thick, polished clear fused quartz was used as an insulating dielectric barrier covering the $2.54 \mathrm{~cm}$ diameter copper electrode. The discharge gap between the bottom of the quartz and the treated skin or wound surface was fixed at $1.5 \mathrm{~mm}$ using a special electrode holder (Figure 1, a) or a modified planar electrode (Figure 1, b). Discharge power density was measured to be $0.13 \mathrm{~W} / \mathrm{cm} 2$ (at $500 \mathrm{~Hz}$ ), $0.15 \mathrm{~W} / \mathrm{cm}^{2}$ (at $800 \mathrm{~Hz}$ ), $0.17 \mathrm{~W} / \mathrm{cm} 2$ (at $1 \mathrm{kHz}$ ), and $0.31 \mathrm{~W} / \mathrm{cm} 2$ (at $1.5 \mathrm{kHz}$ ). Rotational and vibrational temperatures were measured to be $313.5 \pm 7.5 \mathrm{~K}$ and $3360 \pm 50 \mathrm{~K}$ respectively ${ }^{43}$.

\section{B. Microsec ond Pin-to-Hole Spark Discharge (PHD)}

Atmospheric pressure spark discharge was generated in a pin-to-hole electrode configuration similarly as $\mathrm{in}^{44,45}$. A needle anode (1.5 mm diameter) was coaxially fixed in an insulator with gas inlet openings (room air at $\sim 0.5 \mathrm{~L} / \mathrm{min}$ ), which is surrounded by an outer cylindrical cathode ( $7 \mathrm{~mm}$ diameter) with an axial opening ( $2 \mathrm{~mm}$ diameter) for plasma outlet (Figure 2). Both electrodes were made of stainless steel. For all experiments, the plasma discharge was ignited by applying a $4 \mathrm{kV}$ positive potential to the central electrode. To provide high discharge energy while keeping average gas temperature low the electrode system was powered through a $0.33 \mu \mathrm{F}$ capacitor. This formed a $35 \mu$ s dense energetic discharge with average energy of $\sim 1.8 \mathrm{~J} /$ pulse. The average gas temperature was measured using a K-type thermocouple as a function of distance from the cathode (Figure 3). The plasma temperature was calculated as $9030 \pm 320 \mathrm{~K}$ by the Boltzmann method, which was adequate to produce nitric oxide, although the average gas temperature was near room temperature ${ }^{46,47}$. The PHD plasma discharge radiates intensively in the UV range: the measured total plasma UV irradiation with and without gas feeding was 90 and $140 \mu \mathrm{W} / \mathrm{cm}^{2}$ respectively ${ }^{47}$. DNA damage by UV-C and UV-B radiation occurs after about $0.4 \mathrm{~mJ} / \mathrm{cm}^{2}$ and $10 \mathrm{~mJ} / \mathrm{cm}^{2}$ respectively ${ }^{48,49}$. The discharge 
a
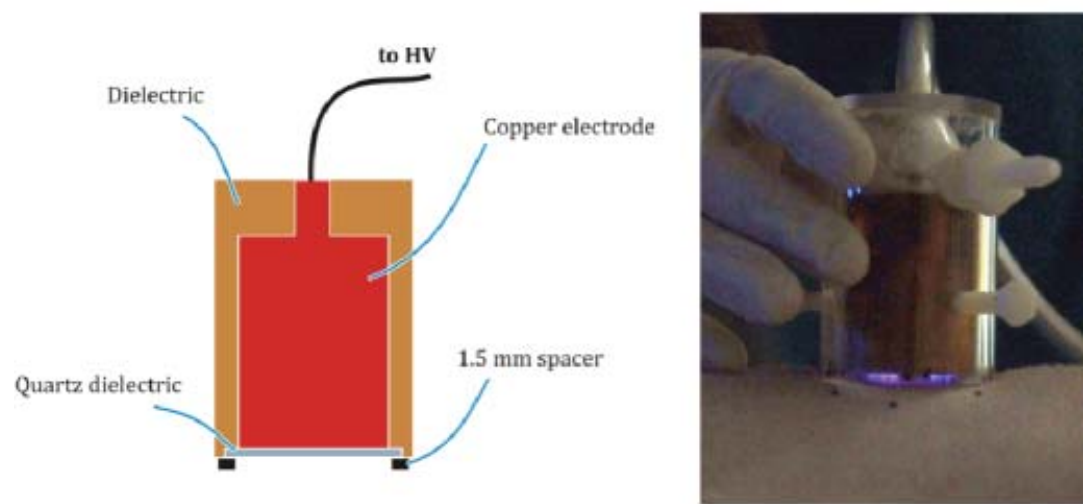

b
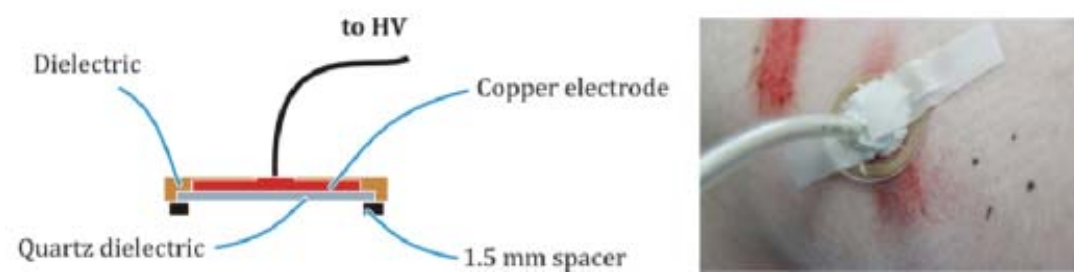

FIGURE 1. General schematics and photographs of the FE-DBD electrodes: conventional (a), and modified planar (b).
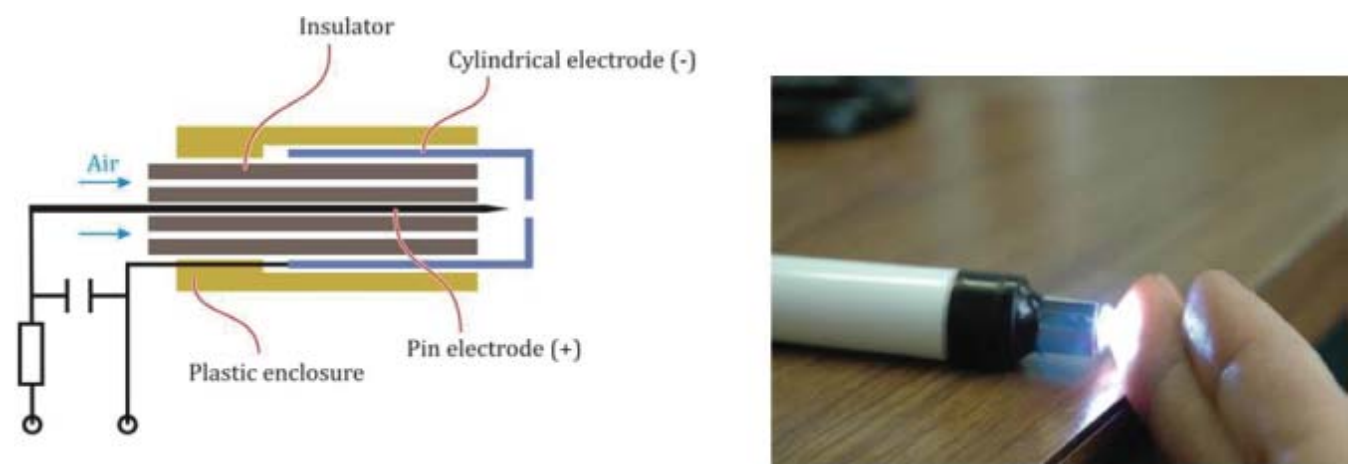

FIGURE 2. General schematic of the PHD electrode (left), and a photograph of the discharge in operation (right).

produces hydrogen peroxide in liquid (PBS) with concentration up to $60 \mu \mathrm{M}$ in about 30 seconds of treatment (210 pulses $)^{47}$. Plasma-produced nitric oxide in gas reached 2000 ppm and rapidly diffused into liquid and cells: 1400 - 1600 nM NO was detected in PBS and $1000 \mathrm{nM}$ NO was detected in endothelial cells immediately following 240 


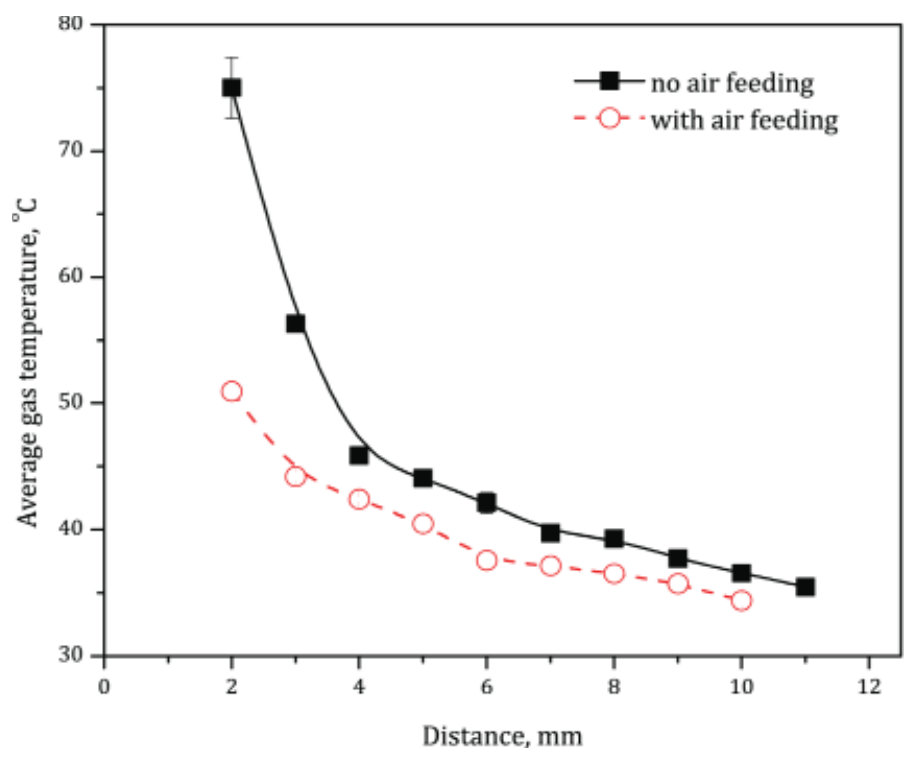

FIGURE 3. PHD afterglow gas temperature measured with thermocouple as a function of distance from the cathode.

plasma pulses ${ }^{46}$. These data suggest that this plasma may provide a novel method for delivering NO locally and directly for enhanced wound healing.

\section{Animal Model}

We evaluated the potential toxic effects of the FE-DBD and PHD plasmas on both intact and wounded porcine skin in 12 Yorkshire pigs. Standard operative procedure included the following: the pig was anesthetized and the dorsum of the pig was marked and divided for treatment areas (Figure 4, a). When intact skin toxicity was studied, the FEDBD electrode was placed $1.5 \mathrm{~mm}$ above the skin, and plasma was applied for different doses by varying the power and time of treatment. Spark discharge was applied at fixed power at a $5 \mathrm{~mm}$ distance from the skin for various amounts of time. When wounded skin was studied, a dermatome knife was used to create a skin abrasion (Figure 4, b), removing about $2 \times 3 \mathrm{~cm}$ of the epidermis and dermis (approximately $3 \mathrm{~mm} \pm 1 \mathrm{~mm}$ deep), followed by plasma treatment. Pigs were then sacrificed immediately or 24 hours after the treatment. Tissue specimens from each treatment area were harvested and sent for histopathologic analysis.

For the intact skin model (3 pigs) of treatment with FE-DBD, we had a total of 85 treatment areas on the three pigs that were harvested 24 hours after surgery. One area of intact skin $(n=3)$ was treated with a high frequency desiccator (positive control, Bovie ${ }^{\circledR}$, Figure $4, c)$, and one area of intact skin $(n=3)$ was left untreated (negative control). The remaining 80 areas were treated with 4 discharge frequency (power) settings for different time points: from 30 seconds, and up to 15 minutes (Table 1). 

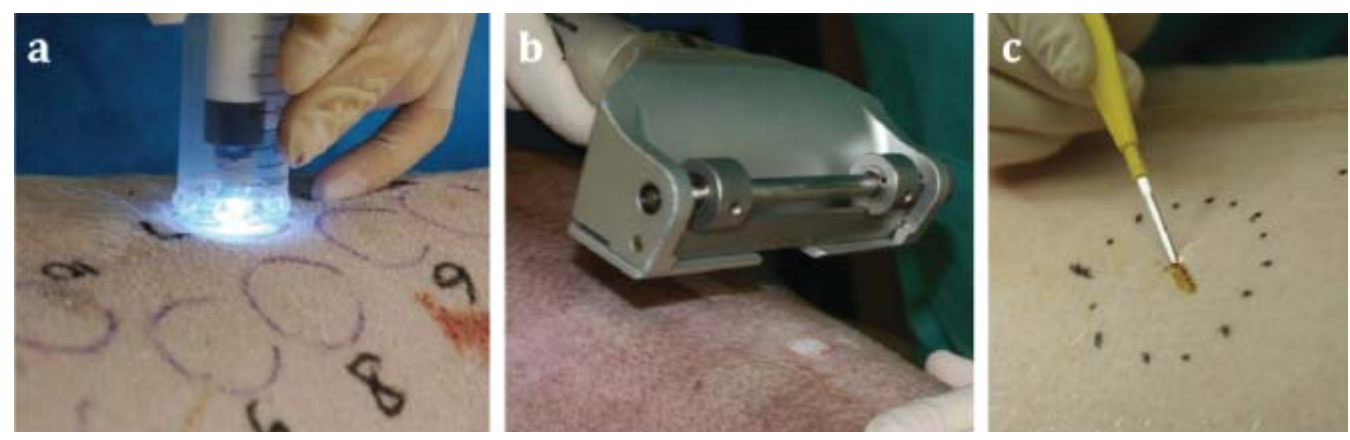

FIGURE 4. Marked treatment areas of the pig skin (a), creation of skin abrasion with dermatome (b), and skin treatment with a high frequency desiccator Bovie ${ }^{\circledR}$, positive control (c).

TABLE 1. Number of areas for intact skin FE-DBD plasma treatment and corresponding exposure dose (in $\mathrm{J} / \mathrm{cm}^{2}$ )

\begin{tabular}{|c|c|c|c|c|}
\hline \multirow{2}{*}{$\begin{array}{l}\text { Treatment time, } \\
\text { min }\end{array}$} & \multicolumn{4}{|c|}{ FE-DBD frequency, kHz (corresponding power density, W/cm²) } \\
\hline & $0.5(0.13)$ & $0.8(0.15)$ & $1.0(0.17)$ & $1.5(0.31)$ \\
\hline 0.5 & - & - & $3\left(5.1 \mathrm{~J} / \mathrm{cm}^{2}\right)$ & $3\left(9.3 \mathrm{~J} / \mathrm{cm}^{2}\right)$ \\
\hline 1 & - & $4\left(9 \mathrm{~J} / \mathrm{cm}^{2}\right)$ & $7\left(10.2 \mathrm{~J} / \mathrm{cm}^{2}\right)$ & $9\left(18.6 \mathrm{~J} / \mathrm{cm}^{2}\right)$ \\
\hline 2 & $2\left(15.6 \mathrm{~J} / \mathrm{cm}^{2}\right)$ & $4\left(18 \mathrm{~J} / \mathrm{cm}^{2}\right)$ & $5\left(20.4 \mathrm{~J} / \mathrm{cm}^{2}\right)$ & $7\left(37.2 \mathrm{~J} / \mathrm{cm}^{2}\right)$ \\
\hline 3 & - & $8\left(27 \mathrm{~J} / \mathrm{cm}^{2}\right)$ & $4\left(30.6 \mathrm{~J} / \mathrm{cm}^{2}\right)$ & $5\left(55.8 \mathrm{~J} / \mathrm{cm}^{2}\right)$ \\
\hline 5 & - & $5\left(45 \mathrm{~J} / \mathrm{cm}^{2}\right)$ & $2\left(51 \mathrm{~J} / \mathrm{cm}^{2}\right)$ & $5\left(93 \mathrm{~J} / \mathrm{cm}^{2}\right)$ \\
\hline 15 & $2\left(117 \mathrm{~J} / \mathrm{cm}^{2}\right)$ & $2\left(135 \mathrm{~J} / \mathrm{cm}^{2}\right)$ & - & - \\
\hline
\end{tabular}

For the wounded skin model (4 pigs) treated with FE-DBD, we had a total of 56 treatment areas on 2 pigs harvested immediately after treatment, and 38 treatment areas on 2 pigs harvested 24 hours after procedure. Animals were treated with two discharge power settings for various amounts of time (see Table 2) using planar DBD electrode, with a high frequency desiccator $(n=8)$, or left untreated as control $(n=7)$.

TABLE 2. Number of areas for intact skin FE-DBD plasma treatment and corresponding exposure dose (in $\mathrm{J} / \mathrm{cm}^{2}$ )

\begin{tabular}{|c|c|c|}
$\begin{array}{c}\text { Treatment time, } \\
\text { min }\end{array}$ & FE-DBD frequency, kHz (corresponding power density, W/cm ${ }^{2}$ ) \\
$\mathbf{0 . 5}(\mathbf{0 . 1 3})$ & $\mathbf{1 . 5}(\mathbf{0 . 3 1})$ \\
\hline 0.5 & $6\left(3.9 \mathrm{~J} / \mathrm{cm}^{2}\right)$ & $6\left(9.3 \mathrm{~J} / \mathrm{cm}^{2}\right)$ \\
\hline 1 & $8\left(7.8 \mathrm{~J} / \mathrm{cm}^{2}\right)$ & $8\left(18.6 \mathrm{~J} / \mathrm{cm}^{2}\right)$ \\
\hline 3 & $9\left(23.4 \mathrm{~J} / \mathrm{cm}^{2}\right)$ & $9\left(55.8 \mathrm{~J}^{2} \mathrm{~cm}^{2}\right)$ \\
\hline 5 & $9\left(39 \mathrm{~J} / \mathrm{cm}^{2}\right)$ & $9\left(93 \mathrm{~J} / \mathrm{cm}^{2}\right)$ \\
\hline 15 & $6\left(117 \mathrm{~J}^{2} \mathrm{~cm}^{2}\right)$ & $7\left(279 \mathrm{~J} / \mathrm{cm}^{2}\right)$ \\
\hline
\end{tabular}

For the intact and wounded skin model (5 pigs) treated with PHD, we had a total 
of 39 (intact skin) and 36 (wounded skin) treatment areas on 4 pigs that were harvested immediately after the procedure, and 48 (intact skin) and 36 (wounds) treatment areas on 4 animals that were harvested 24 hours after plasma exposure. Skin was treated with spark plasma at $5 \mathrm{~mm}$ for 5 to 300 seconds (see Table 3).

TABLE 3. Number of areas for intact and wounded skin PHD plasma treatment

\begin{tabular}{|c|c|c|}
\hline Treatment time, s & $5 \mathrm{~mm}$, intact skin & $5 \mathrm{~mm}$, wounds \\
\hline 5 & $\begin{array}{c}2 \text { (non-survival) } \\
4 \text { (survival) }\end{array}$ & $\begin{array}{c}2 \text { (non-survival) } \\
2 \text { (survival) }\end{array}$ \\
\hline 15 & $\begin{array}{c}2 \text { (non-survival) } \\
4 \text { (survival) }\end{array}$ & $\begin{array}{c}4 \text { (non-survival) } \\
4 \text { (survival) }\end{array}$ \\
\hline 30 & $\begin{array}{c}2 \text { (non-survival) } \\
4 \text { (survival) }\end{array}$ & $\begin{array}{c}4 \text { (non-survival) } \\
4 \text { (survival) }\end{array}$ \\
\hline 60 & $\begin{array}{c}2 \text { (non-survival) } \\
4 \text { (survival) }\end{array}$ & $\begin{array}{c}4 \text { (non-survival) } \\
4 \text { (survival) }\end{array}$ \\
\hline 90 & 2 (survival) & - \\
\hline 120 & $\begin{array}{c}6 \text { (non-survival) } \\
4 \text { (survival) }\end{array}$ & - \\
\hline 180 & $\begin{array}{c}5 \text { (non-survival) } \\
4 \text { (survival) }\end{array}$ & $\begin{array}{c}4 \text { (non-survival) } \\
4 \text { (survival) }\end{array}$ \\
\hline 240 & 2 (survival) & - \\
\hline 300 & 4 (non-survival) & - \\
\hline
\end{tabular}

\section{Histological Analysis}

All specimens were analyzed with microscopic histological analysis. Specimens were longitudinally sectioned and fixed for 24 hours in formalin. Sections for histology were processed in a standard fashion and stained with hematoxylin-eosin. The pathologists were blinded to all specimens and categorized each specimen into a burn grading system for the intact and wounded skin data analysis. For intact skin, the specimens were either classified as normal, minimal change, epidermal damage, or full burn through the dermis. For wounded skin, the specimens were either classified as normal, presence of a clot or scab, and full burn through the dermis.

\section{E. pHand Temperature Analysis}

In order to check the change of skin temperature and $\mathrm{pH}$ of the skin sample after plasma treatment, fresh pig skin samples with average thickness of about $1 \mathrm{~cm}$ were placed on aluminum foil and kept at constant initial temperature of about $37^{\circ} \mathrm{C}$. Skin samples were exposed to both discharges for the same amount of time as in in-vivo study. These changes were monitored using infrared thermometer (OS53x-CR, Omega) and skin pH/ temperature meter (HI 99181, Hanna). 
All procedures were performed in compliance with the animal welfare and protection act following the Drexel University's Institutional Animal Care and Use Committee (IACUC) approval, Protocols \#17030 (intact skin) and \#17335 (wounded skin).

\section{RESULTS AND DISCUSSION}

Endpoints for toxicity analysis consisted of recording both gross and histological examination of the intact skin and wounded skin specimens. Gross observation was correlated with the histological grading system as mentioned previously.

\section{A. Treatment of Intact Skin}

FE-DBD plasma treatment was evaluated on 3 pigs with intact skin at 4 different frequency (power) settings, all harvested 24 hours after the procedure. The results for 3 discharge frequencies are shown on Figure 5 in terms of normalized number of observation of no or minimal changes in skin, epidermal damage, or burn after certain treatment dose. Untreated skin appeared normal on gross histological observation. With minimal change, there was a small area of erythema on the skin. With epidermal damage, there was mild erythema that resolved itself usually within 20 minutes. With full burn through the dermis, there was diffuse erythema that remained until time of harvest (Table 4). Positive controls, i. e. samples treated with HF desiccator, all showed full thickness burn. Representative photographs and histological images are shown in Table 4. One can notice that resulting toxic effects (epidermal damage, burn) depends not only on the exposure dose, but dose rate (frequency dependent): the higher the frequency, the lower dose required for skin damage to occur.

The results of intact skin treatment with spark discharge plasma at $5 \mathrm{~mm}$ distance from the skin are shown in Figure 6 and in Table 4. In this case a burn was observed after 3 minutes of treatment, while, for example, inactivation of bacteria in liquid requires an exposure time of several seconds ${ }^{44,45}$.

Overall results of the skin toxicity trials on pigs are similar to those on human cadaver skin and on SKH1 mice ${ }^{39,42}$ - only rather high doses of plasma, those far greater than needed for sterilization or blood coagulation, are able to damage skin; while doses required to achieve desired medically relevant therapeutic effect are significantly below the damage threshold.

\section{B. Ex-vivo Treatment of Porc ine Skin Samples}

In order to estimate the effect of global increase of temperature and $\mathrm{pH}$ of skin after the plasma treatment on induction of tissue damage, we have measured these parameters on skin samples ex vivo. The results of temperature measurements (Figure 7, a) indicate, that after about 3 minutes of treatment by both plasmas, skin temperature increases by 11-14 degrees, which is the critical temperature for skin burn ${ }^{50,51}$, and is in good agreement with our experimental observations (see Figure 5 and Figure 6). The effect of the decrease of $\mathrm{pH}$ due to plasma treatment is probably negligible for both discharges (Figure 7, b). 

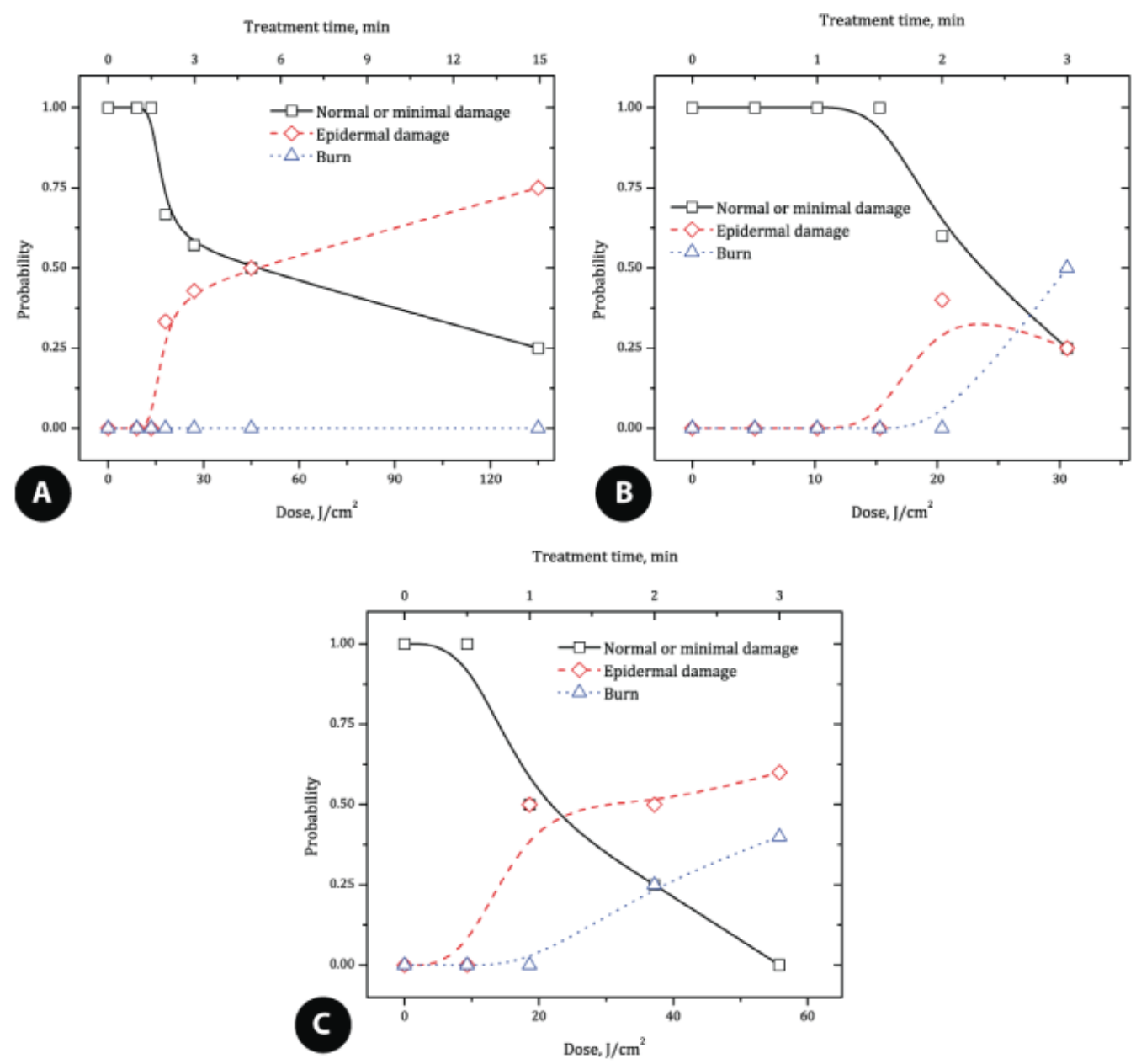

FIGURE 5. Results of the intact porcine skin treatment with FE-DBD plasma operated at 800 (a), 1000 (b) and 1500 (c) Hz frequency.

\section{Toxic ity of Wound Treatment}

One of the potential applications of FE-DBD and spark plasma treatment is sterilization and healing of wounds and/or coagulation of bleeding capillaries (see end of section II.B above). We were able to test the efficacy and toxicity of such treatment on a superficial partial thickness skin wound similar to that of scraping one's knee. Once the animal was anaesthetized the wound was made with a small hand-held dermatome knife (Zimmer, Franklin County, OH, USA) originally designed to remove precise-thickness skin grafts from a donor surface. These are partial thickness wounds with the blade set to cut no deeper than a millimeter into the skin. This exposes the top layer of skin and breaks 


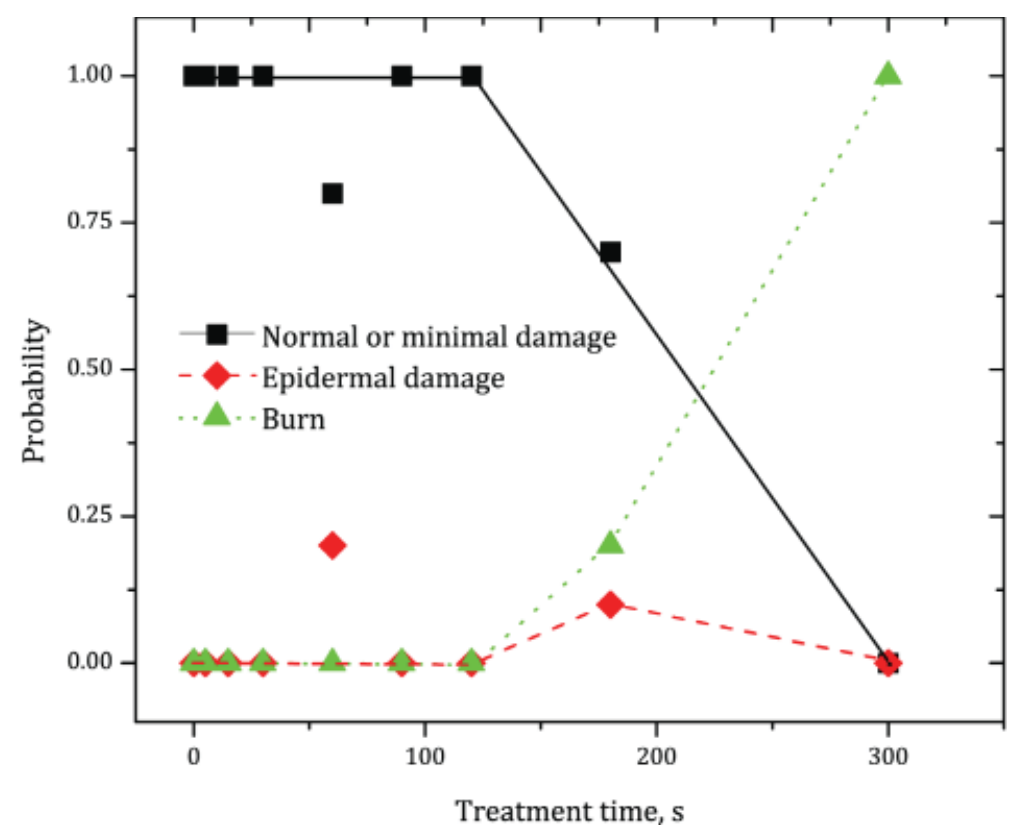

FIGURE 6. Results of the intact porcine skin treatment with PHD plasma operated at $5 \mathrm{~mm}$ distance from the skin surface.

capillaries located in the skin, but not the bigger vessels. Thus, the bleeding is slow and manageable. This is not a severe wound and the bleeding would normally self-terminate quickly. Immediately after the wound is made we proceed with the selected treatment.

Results of the various FE-DBD and PHD plasma treatments of wound surface and histological images of these skin samples are detailed in Table 5. Similar to the intact skin, treatment with Bovie ${ }^{\circledR}$ knife quickly coagulates blood and desiccates the tissue but causes quite significant damage (see Table 5). Although the wound may be closed, there is a significant level of tissue damage which may prolong the wound healing process over that if the wound was simply left with no treatment in this case. While the Bovie ${ }^{\circledR}$ electrosurgery knife causes significant tissue damage, both plasma treatments can be applied to the tissue for up to 15 minutes with no or minimal damage to this tissue (Table 5). One other observation is that even after a short treatment, the blood appears to be coagulated and (although this is not visible on the photograph below) the wound looks to be covered with a thin layer of clear coagulum. We have seen such a thin transparent cork formation before with treatment of blood and blood plasma samples ${ }^{39,42}$. This film was claimed to be a thin layer of coagulated blood plasma - both FE-DBD and PHD seem to quickly form a layer of coagulated blood on the surface of the wound which protects the wound from further external disturbances. 
TABLE 4. Representative photographs and histological images of the intact skin after treatment with FE-DBD and PHD plasmas.

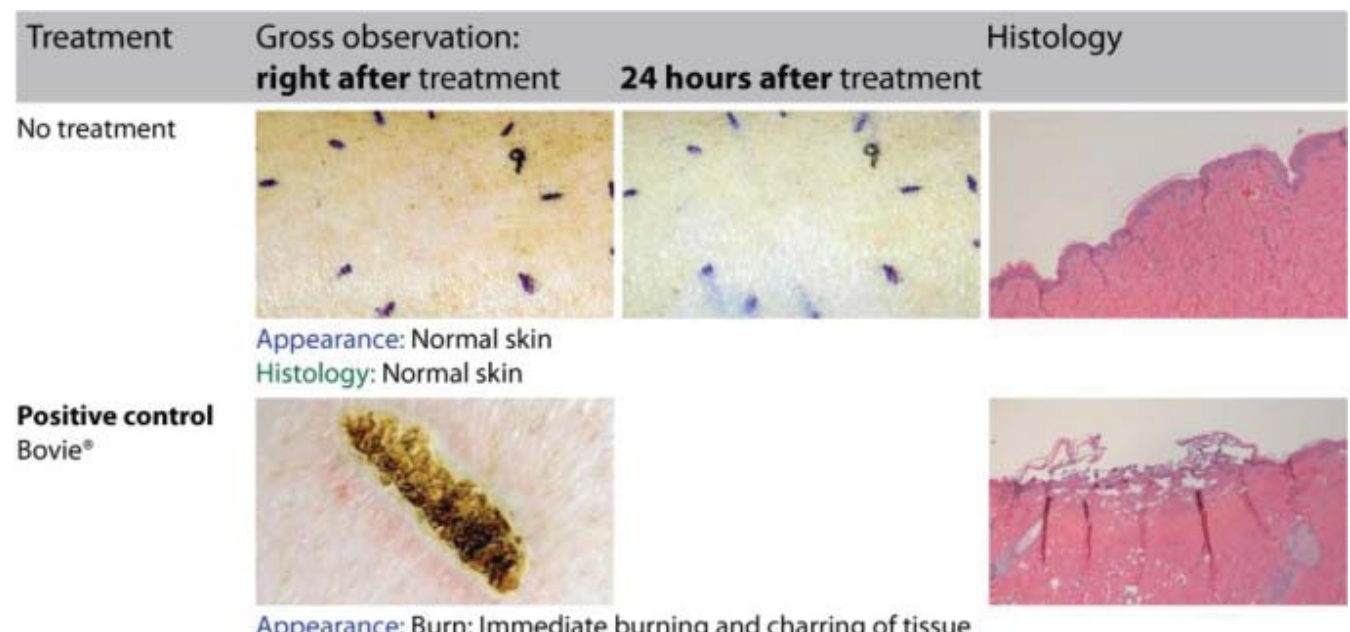

Appearance: Burn: Immediate burning and charring of tissue

Histology: Disruption of epidermis and papillary dermis, areas of dermis coagulated, no dermal nuclei, hair follicles still intact

FE-DBD

$45 \mathrm{~J} / \mathrm{cm}^{2}$

5 min@ $0.8 \mathrm{kHz}$

FE-DBD

$135 \mathrm{~J} / \mathrm{cm}^{2}$

$15 \mathrm{~min} @ 0.8 \mathrm{kHz}$

FE-DBD

$37.2 \mathrm{~J} / \mathrm{cm}^{2}$

$2 \mathrm{~min} @ 1.5 \mathrm{kHz}$
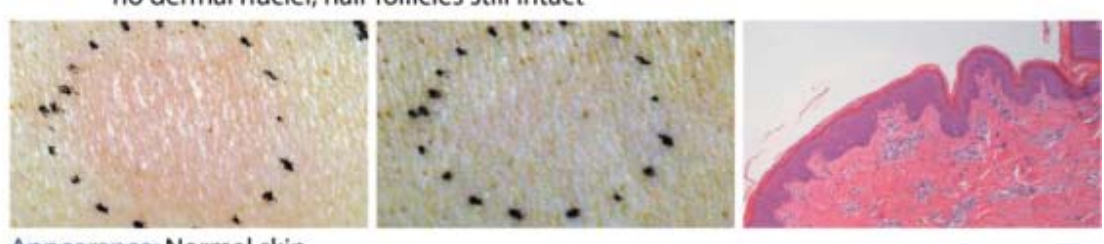

Appearance: Normal skin Histology: Normal skin
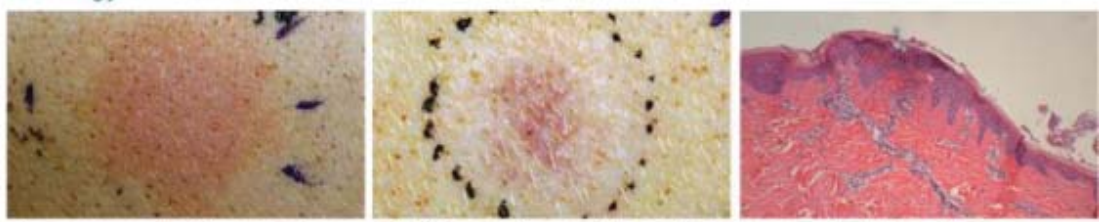

Appearance: Epidermal damage; Diffuse redness with a distinct area of mild erythema Histology: Small area of burn in epidermis
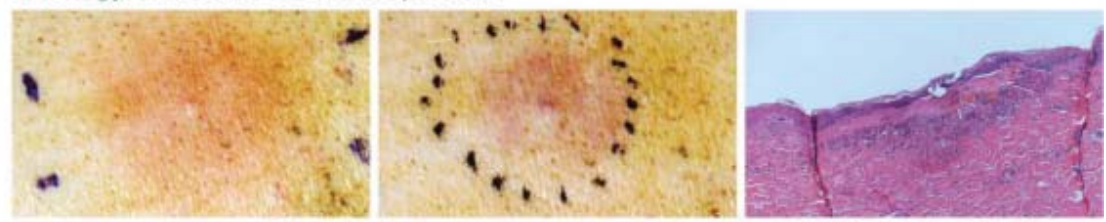

Appearance: Burn Small Central area of increasing redness surrounded by erythema after 1 min treatment. Area of necrosis forming centrally surrounded by area of erythema Histology: Similar to Bovie ${ }^{\circ}$, burn through to dermis

\section{CONCLUSON}

The purpose of this work was to determine the toxic doses of cold plasma treatment of living tissue for both intact and wounded skin. In this study we have used a well- 
TABLE 4. Representative photographs and histological images of the intact skin after treatment with FE-DBD and PHD plasmas. (Continued)

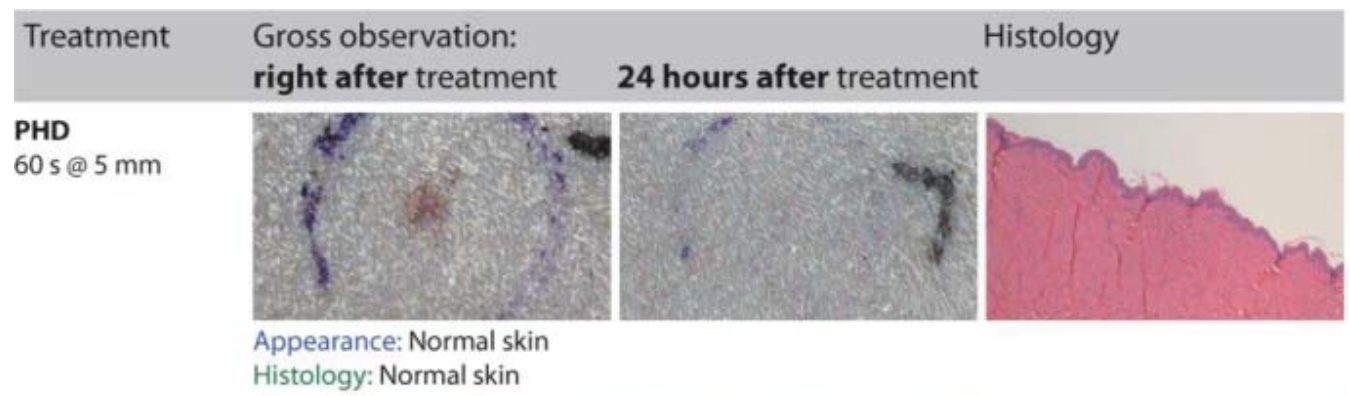

PHD

$180 \mathrm{~s} @ 5 \mathrm{~mm}$
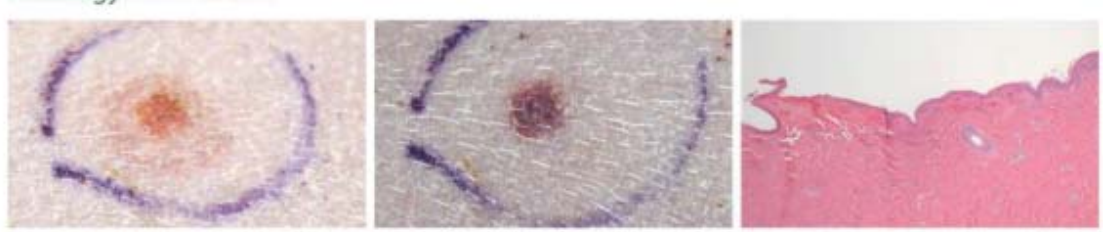

Appearance: Burn

Histology: Similar to Bovie", burn through to dermis
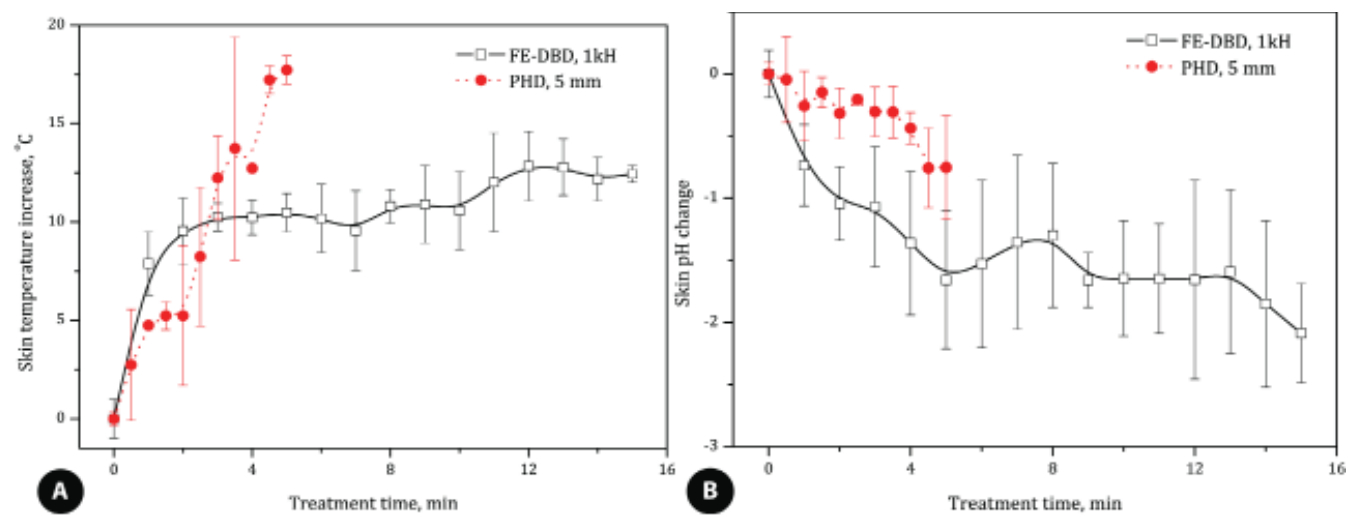

FIGURE 7. The results of temperature (a) and $\mathrm{pH}(\mathrm{b})$ measurements of the porcine skin ex-vivo treatment with FE-DBD and PHD plasmas.

established method for evaluation of tissue toxicity, where a Yorkshire pig intact or wounded skin was exposed to a plasma source and macroscopic toxic effects were studied histologically. In order to evaluate the possible source of plasma toxicity, we have used two plasma sources in which discharges are ignited and applied in completely different ways - direct non-thermal dielectric barrier discharge, and indirect thermal spark discharge. The results of our study show that, despite the fundamental differences of these two discharges, toxic effects (epidermal damage and tissue burn) are related to global increase of temperature of the treated skin, and are highly dependant not only on the dose of plasma exposure, but also on the dose rate - the lower the frequency of a discharge, the higher plasma dose may be applied to skin without damaging it. Plasma 
TABLE 5. Representative photographs and histological images of the wounded skin after treatment with FE-DBD and PHD plasmas.

$\begin{array}{lll}\text { Treatment } & \text { Gross observation } & \text { Histology } \\ \text { No treatment } & & \\ & & \end{array}$

\section{Positive control}

Bovie*

FE-DBD

Histology: Normal wound

$117 \mathrm{~J} / \mathrm{cm}^{2}$

$15 \mathrm{~min} @ 0.5 \mathrm{kHz}$
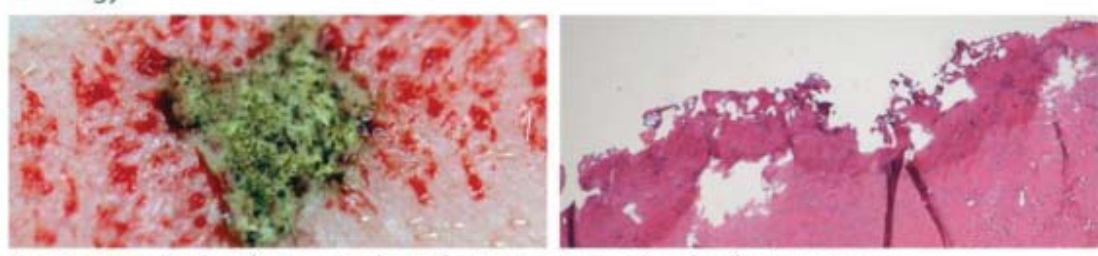

Appearance: Eschar formation, burn formation immediately after treatment Instant blood coagulation Necrotic tissue

Histology: Necrosis deep in the dermis. Disruption of the dermis. No dermal nuclei. Hair follicles still intact
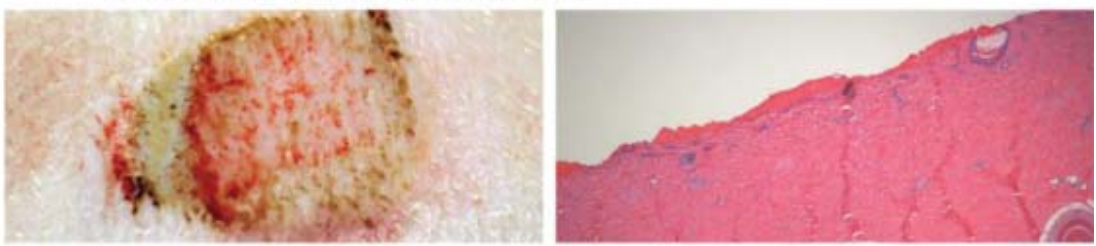

Appearance: No burn. Blood clot formation

Histology: Clot on surface. No damage to wound tissue. Intact hair follicles

FE-DBD

$93 \mathrm{~J} / \mathrm{cm}^{2}$

5 min@1.5 kHz
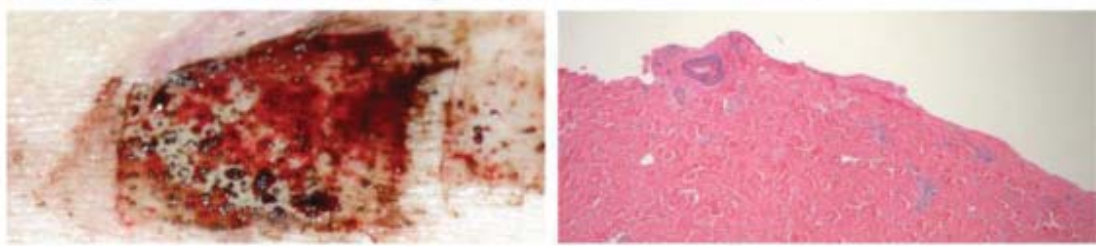

Appearance: No burn. Coagulation.

Histology: Clot on the surface of the wound. No damage to wound tissue.

PHD

$180 \mathrm{~s} @ 5 \mathrm{~mm}$
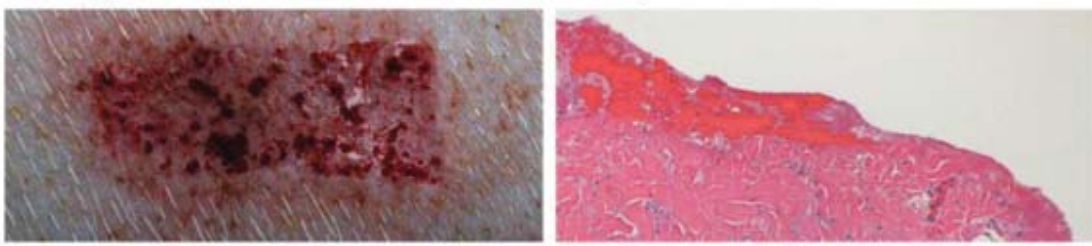

Appearance: No burn. Coagulation

Histology: Clot visible. No damage to dermis. Intact hair follicles. 
treatment of wounded tissue, on the other hand, did not result in any toxic effects to the tissue itself, but in effective and fast blood coagulation. This blood clot, apparently, protected underlying wound tissue from plasma damage. Overall, we have shown that plasma treatment is safe for living intact and wounded skin when applied for doses several times higher than required for effective inactivation of bacteria on surface of agar or in liquid. In the future studies we plan to expand on these findings, analyzing the dose and dose rate dependence; we also plan to reduce surface temperature by creating more uniform shorter pulse plasmas.

\section{REFERENCES}

1. Weltman KD, Dieter K, Kindel E, von Woedtke T, Hähnel M, Stieber M, Brandenburg R. Atmospheric-pressure plasma sources: Prospective tools for plasma medicine. Pure and Applied Chemistry, 2010;82(6):1223-1237.

2. Cheruthazhekatt S, Cernak M, Slavicek P, Havel J. Gas plasmas and plasma modified materials in medicine. Journal of Applied Biomedicine, 2010;8(2):55-66.

3. Lloyd G, Friedman G, Jafri S, Schultz G, Fridman A, Harding K. Gas Plasma: Medical Uses and Developments in Wound Care. Plasma Processes and Polymers, 2010;7(3-4):194-211:115011.

4. Morfill GE, Kong MG, Zimmermann JL. Focus on Plasma Medicine. New Journal of Physics, 2009; 11 .

5. Kong MG, Kroesen G, Morfill G, Nosenko T, Shimizu T, van Dijk J, Zimmerman JL. Plasma medicine: an introductory review. New Journal of Physics, 2009;11:115012.

6. Dobrynin D, Fridman G, Friedman G, Fridman A. Physical and biological mechanisms of direct plasma interaction with living tissue. New Journal of Physics, 2009;11:115020.

7. Massines F, Gherardi N, Naudé N, Ségur P. Recent advances in the understanding of homogeneous dielectric barrier discharges. European Physical Journal-Applied Physics, 2009;47(2):21-24.

8. Laroussi M. Low-Temperature Plasmas for Medicine? Ieee Transactions on Plasma Science, 2009;37(6):714-725.

9. Vasilets VN, Gutsol A, Shekhter AB, Fridman A. Plasma medicine. High Energy Chemistry, 2009;43(3):229-233.

10. Fridman G, Friedman G, Gutsol A, Shekhter AB, Vasilets VN, Fridman A. Applied Plasma Medicine. Plasma Processes and Polymers, 2008;5(6):503-533.

11. Babaeva NY, Kushner MJ. Intracellular electric fields produced by dielectric barrier discharge treatment of skin. Journal of Physics D-Applied Physics, 2010;43(18):185206.

12. Cao Z, Nie Q, Bayliss DL, Walsh JL, Ren CS, Wang DZ, Kong MG. Spatially extended atmospheric plasma arrays. Plasma Sources Science \& Technology, 2010;19(2):025003.

13. Walsh JL, Iza F, Janson NB, Law VJ, Kong MG. Three distinct modes in a cold atmospheric pressure plasma jet. Journal of Physics D-Applied Physics, 2010;43(7) :075201. 
14. Sarrette JP, Cousty S, Merbani N, Négre-Salvayre A, Clément F. Observation of antibacterial effects obtained at atmospheric and reduced pressures in afterglow conditions. European Physical Journal-Applied Physics, 2010;49(1):13108.

15. Nosenko T, Shimizu T, Morfill GE. Designing plasmas for chronic wound disinfection. New Journal of Physics, 2009;11:115011.

16. Martines E, Zuin M, Cavazzana R, Gazza E, Serianni G, Spagnolo S, Spolare M, Leonardi A, Deligianni V, Brun P, Aragona M, Castagliuolo I. A novel plasma source for sterilization of living tissues. New Journal of Physics, 2009;11:115014.

17. Nie QY, Cao Z, Ren CS, Wang DZ, Kong MG. A two-dimensional cold atmospheric plasma jet array for uniform treatment of large-area surfaces for plasma medicine. New Journal of Physics, 2009;11:115015.

18. Morfill GE, Shimizu T, Steffes B, Schmidt -U. Nosocomial infections-a new approach towards preventive medicine using plasmas. New Journal of Physics, 2009;11:115019.

19. Lu X, Xiong X, Zhao F, Xian Y, Xiong Q, Gong W, Zou C, Jiang Z, Pan Y. A simple atmospheric pressure room-temperature air plasma needle device for biomedical applications. Applied Physics Letters, 2009;95(18):181501.

20. Choi J, Matsuo K, Yoshida H, Namihira T, Katsuki S, Akiyama H. Double-Layered Atmospheric Pressure Plasma Jet. Japanese Journal of Applied Physics, 2009;48(8):086003.

21. Staack D, Farouk B, Gutsol A, Fridman A. Stabilization of the ionization overheating thermal instability in atmospheric pressure microplasmas. Journal of Applied Physics, 2009;106(1):013303.

22. Bekstein A, Yousif M, Bentienni M, Ducasse O, Eichwald O. Drift and reactions of positive tetratomic ions in dry, atmospheric air: Their effects on the dynamics of primary and secondary streamers. Journal of Applied Physics, 2010;107(10):103308.

23. Rauscher H, Kylián O, Benedikt J, von Keudell A, Rossi F. Elimination of Biological Contaminations from Surfaces by Plasma Discharges: Chemical Sputtering. Chemphyschem, 2010;11(7):1382-1389.

24. Yousfi M, Bekstein A, Merbani N, Eichwald O, Ducasse O, Benhenni M, Gardou JP. Basic data for atmospheric pressure non-thermal plasma investigations in environmental and biomedical applications. Plasma Sources Science \& Technology, 2010;19(3):034004.

25. Malovic G, Puač N, Lazovic S, Petrovic Z. Mass analysis of an atmospheric pressure plasma needle discharge. Plasma Sources Science \& Technology, 2010;19(3):034014.

26. Jiang N, Cao ZX. Experimental studies on an atmospheric pressure He plasma jet. Acta Physica Sinica, 2010;59(5):3324-3330.

27. Xiong Q, Lu XP, Ostrikov K, Xian Y, Zou C, Ziong Z, Pay Y. Pulsed dc- and sine-waveexcited cold atmospheric plasma plumes: A comparative analysis. Physics of Plasmas, 2010;17(4):043506.

28. Shashurin A, Shneider MN, Dogariu A, Miles RB, Keidar M. Temporary-resolved measurement of electron density in small atmospheric plasmas. Applied Physics Letters, 2010;96(17):171502.

29. Xiong Q, Lu X, Xian Y, Liu J, Zou C, Xiong Z, Gong W, Chen K, Pei X, Zou F, Hu J, Jiang Z, Pan Y. Experimental investigations on the propagation of the plasma jet in the open air. Journal of Applied Physics, 2010;107(7):073302.

30. Park GY, Hong YJ, Lee HW, Sim JY, Lee JK. A Global Model for the Identification of the Dominant Reactions for Atomic Oxygen in He/O-2 Atmospheric-Pressure Plasmas. Plasma 
Processes and Polymers, 2010;7(3-4):281-287.

31. Xian Y, Lu X, Tang Z, Xiong Q, Gong W, Liu D, Jiang Z, Pan Y. Optical and electrical diagnostics of an atmospheric pressure room-temperature plasma plume. Journal of Applied Physics, 2010;107(6):063308.

32. Sato T, Ochiai S, Urayama T. Generation and transport mechanisms of chemical species by a post-discharge flow for inactivation of bacteria. New Journal of Physics, 2009;11, 11:115018.

33. Helmke A, Hoffmeister D, Mertens N, Emmert S, Schuette J, Vioel W. The acidification of lipid film surfaces by non-thermal DBD at atmospheric pressure in air. New Journal of Physics, 2009;11,11:115025.

34. van Dijk J, Kroesen GMW, Bogaerts A. Plasma modelling and numerical simulation. Journal of Physics D-Applied Physics, 2009;42(19):190301.

35. Isbary G, Morfill G, Schmidt HU, Georgi M, Ramrath K, Heinlin J, Karrer S, Landthaler M, Shimizu B, Steffes B, Bunk W, Monetti R, Zimmerman JL, Pompl R, Stolz W. A first prospective randomized controlled trial to decrease bacterial load using cold atmospheric argon plasma on chronic wounds in patients. British Journal of Dermatology, 2010;163(1):78-82.

36. Weltmann KD, Kindel R, Brandenburg R, Meyer C, Bussiahn R, Wilke C, von Woedtke T. Atmospheric Pressure Plasma Jet for Medical Therapy: Plasma Parameters and Risk Estimation. Contributions to Plasma Physics, 2009;49(9):631-640.

37. Fridman G, Peddinghaus M, Balasubramanian H, Ayan H, Fridman A, Gutsol A, Brooks A. Blood coagulation and living tissue sterilization by floating-electrode dielectric barrier discharge in air. Plasma Chemistry and Plasma Processing, 2006. 26(4): p. 425-442.

38. Dobrynin D, Friedman G, Fridman A. Physical and biological mechanisms of direct plasma interaction with living tissue New J. Phys., 2009;11:115020.

39. Fridman G, Peddinghaus M, Balasubramanian H, Ayan H, Fridman A, Gutsol A, Brooks A. Blood coagulation and living tissue sterilization by floating-electrode dielectric barrier discharge in air. Plasma Chemistry and Plasma Processing, 2006;26(4):425-442.

40. Fridman G, Brooks AD, Balasubramanian M, Fridman A, Gutsol A, Vasilets VN, Ayan H, Friedman G. Comparison of Direct and Indirect Effects of Non-Thermal Atmospheric Pressure Plasma on Bacteria. Plasma Processes and Polymers, 2007;4:370-375.

41. Fridman G, Shereshevsky A, Jost M, Brooks A, Fridman A, Gutsol A, Vasilets V, Friedman G. Floating Electrode Dielectric Barrier Discharge Plasma in Air Promoting Apoptotic Behavior in Melanoma Skin Cancer Cell Lines. Plasma Chemistry and Plasma Processing, 2007;27(2):163-176.

42. Fridman G, Shekhter AB, Vasilets VN, Friedman G, Gutsol A, Fridman A. Applied Plasma Medicine. Plasma Processes and Polymers, 2008;5(6):503-533.

43. Ayan H, Staack D, Fridman G, Gutsol A, Mukhin Y, Starikovskii A, Friedman A. Application of nanosecond-pulsed dielectric barrier discharge for biomedical treatment of topographically non-uniform surfaces. J. Phys. D: Appl. Phys., 2009;42:125202.

44. Gostev V. Cold Plasma in Biological Investigations. in NATO Advanced Study Institute (ASI): Plasma Assisted Decontamination of Biological and Chemical Agents. 2007, Cesme, Turkey.

45. Gostev VaD. D. Medical microplasmatron in 3rd International Workshop on Microplasmas 2006, Greifswald, Germany.

46. Dobrynin D, Barbee KA, Fridman A, Friedman G, Morss-Clyne A. Direct and controllable 
nitric oxide delivery into biological media and living cells by a pin-to-hole spark discharge (PHD) plasma. submitted to Journal of Physics D: Applied Physics, 2010.

47. Dobrynin D, Fridman G, Friedman G. Pin-to-Hole Spark Discharge (PHD) Plasma for Biological and Medical Appliactions, in to appear in Proceedings of the 37th International Conference on Plasma Science. June 20-24, 2010: Norfolk, VA, USA.

48. Landsberg K. Cold atmospheric plasma generated UV light - friend or foe?, in Second International Conference on Plasma Medicine. March 16-20, 2009: San Antonio, Texas, USA.

49. GUIDELINES ON LIMITS OF EXPOSURE TO ULTRAVIOLET RADIATION OF WAVELENGTHS BETWEEN 180 NM AND 400 NM (INCOHERENT OPTICAL RADIATION), T.I.C.o.N.-I.R. Protection, Editor. 2004: Oberschleissheim, Germany.

50. Leach EH. Experimental Termal Burns, Eepecially the Moderate Temperature Burn. Exp Physiol, 1943;32(1):67-86.

51. Suzuki T, Hirayamaa T, Aiharab K, Hirohatab Y. Experimental studies of moderate temperature burns. Burns, 1991;17(6):443-451 